\title{
PELAKSANAAN BAGI HASIL TERNAK KAMBING DENGAN BADAN USAHA MILIK DESA DI DESA SUKA RAMAI PANYABUNGAN UTARA MENURUT HUKUM ISLAM
}

\author{
Anjur Perkasa Alam \\ STAI JM Tanjung Pura \\ Email: anjurpohan@gmail.com
}

\begin{abstract}
This study aims to determine how the implementation of goat production of profit sharing in village-owned enterprises is busy according to Islamic law. The research method used is descriptive qualitative research methods with Islamic law approach. the implementation of goat livestock production sharing with the mudharabah agreement is carried out with the custodian only responsible for maintenance and breeding. In return, the livestock group is entitled to a certain ratio of livestock produce. If viewed under Islamic law, the practice of mudharabah profit sharing in Suka Ramai Village, Kec. Panyabungan Utara District. Mandailing Natal has met the criteria of Islamic law, because the practice of sharing livestock has become a local custom. Whereas in Islamic law custom can be made into law, with the rule of "Customs can be made into law". Does not cause disputes because of mutual approval. The practice of sharing goat livestock is mutually beneficial between the livestock group and the Village-Owned Enterprise. There is a principle of please help. While the wisdom or purpose of cooperation: first, the realization of mutually beneficial cooperation between livestock groups and Village-Owned Enterprises. second, increasing public welfare. third, poverty reduction. fourth, opening up jobs.
\end{abstract}

Keywords: Mudharabah, Profit sharing, BUMD, Islamic Law

\begin{abstract}
Abstrak
Penelitian ini bertujuan untuk mengetahui bagaimana pelaksanaan bagi hasil ternak kambing pada badan usaha milik desa suka ramai panyabungan menurut hukum islam. Metode penelitian yang digunakan adalah metode penelitian kualitatif deskriptif dengan pendekatan hukum islam. pelaksanaan bagi hasil ternak kambing dengan akad mudharabah terlaksana dengan pemelihara hanya bertanggung jawab atas pemeliharaan dan pengembangbiakan. Sebagai imbalan, kelompok ternak berhak atas nisbah tertentu dari hasil ternak. Jika ditinjau secara hukum Islam, praktik bagi hasil mudharabah di Desa Suka Ramai Kec. Panyabungan Utara Kab. Mandailing Natal sudah memenuhi kriteria hukum Islam, karena dengan alasan, Praktik bagi hasil ternak tersebut sudah menjadi adat kebiasaan setempat. Sedangkan dalam hukum Islam adat dapat dijadikan hukum, dengan kaidah "Adat kebiasaan dapat dijadikan hukum". Tidak menimbulkan perselisihan karena saling ridho. Praktik bagi hasil ternak kambing tersebut saling menguntungkan antara kelompok ternak dan pihak Badan Usaha Milik Desa. Adanya asas tolong menolong. Sedangkan hikmah atau tujuan adanya kerjasama : pertama, terwujudnya kerjasama yang saling menguntungkan antara kelompok ternak dengan Badan Usaha Milik Desa. kedua, meningkatnya kesejahteraan
\end{abstract}


masyarakat. ketiga, tertanggulanginya kemiskinan. keempat, terbukanya lapangan pekerjaan.

Kata Kunci: Mudharabah, Bagi hasil, BUMD, Hukum Islam

\section{Pendahuluan}

Islam telah mengajarkan kepada seluruh umat manusia untuk hidup saling tolong-menolong dengan berdasar pada rasa tanggung jawab bersama, jamin menjamin dan tanggung menanggung dalam hidup bermasyarakat. Islam juga mengajarkan agar dalam hidup bermasyarakat dapat ditegakkan nilai-nilai keadilan dan dihindarkan praktik-praktik penindasan dan pemerasan. Agama islam mempunyai dua sumber pokok yang tetap yaitu Al-Qur'an dan Al-Hadits. Diantara salah satu segi hukum yang terdapat di dalamnya adalah masalah-masalah hukum Islam membenarkan seorang muslim berdagang atau usaha perseorangan, membenarkan juga menggabungkan modal dan tenaga dalam bentuk perkongsian ke gotong royongan yang memungkinkan usaha dapat berjalan dengan lancar.

Namun Islam memberi ketentuan atau aturan usaha yang dilakukan baik secara perorangan maupun kelompok, yaitu dikategorikan halal dan mengandung kebaikan. Di dalam perekonomian yang marak sekarang ini adalah dengan menggunakan sistem bagi hasil, ini merupakan bagian dari bentuk kerjasama antara pihak penyedia dana menyertakan modal dan pihak lain sebagai pengelola yang memiliki keahlian (Skill) dan manajemen sehingga tercapai tujuan perekonomian, dan apabila terdapat keuntungan maka hal ini akan dibagi sesuai dengan kesepakatan.

Salah satu serikat yang diperbolehkan adalah mudharabah Secara teknik, bagi hasil adalah akad kerjasama usaha antara dua pihak dimana pihak pertama (shahibul maal) menyediakan seluruh (100\%) modal, sedangkan pihak lainnya menjadi pengelola. Keuntungan usaha secara mudharabah dibagi menurut kesepakatan yang dituangkan dalam kontrak sedangkan apabila rugi ditanggung oleh pemilik modal selama kerugian itu bukan akibat kelalaian si pengelola, si pengelola harus bertanggung jawab atas kerugian tersebut. ${ }^{1}$

Peternakan merupakan salah satu profesi yang lazim dilakukan oleh masyarakat bahkan masyarakat kota sekalipun baik dikelola sendiri maupun dipercayakan kepada orang lain dengan perjanjian membagi dari hasil keuntungan yang diperoleh. Akan tetapi yang perlu dipertanyakan adalah apakah sistem dalam 
menjalankan proses peternakan dan cara membagi hasil keuntungan tersebut sudah memenuhi ketentuan-ketentuan yang diatur dalam syari'ah Islam. Salah satu contoh dalam usaha perkongsian yang banyak terjadi dalam masyarakat di Indonesia khususnya adalah kerja sama bagi hasil yang sifatnya saling menguntungkan kedua belah pihak, yaitu pemilik modal dan penerima modal.

Pada masalah ini Islam memberi ketentuan hanya secara garis besar saja, yaitu apabila orang-orang melakukan apa-apa secara bersama-sama mereka akan menghadapi perbedaan dan perselisihan tentang masalah keuangan. Mudharabah adalah akad kerja sama usaha antara dua pihak. Dimana pihak pertama (shahibul maal) menyediakan seluruh modal, sedangkan pihak lainnya menjadi pengelola, keuntungan usaha secara mudharabah dibagi menurut kesepakatan yang dituangkan dalam kontrak, sedangkan apabila rugi ditanggung oleh pemilik modal selama kerugian itu bukan karena kecurangan atau kelalaian si pengelola. ${ }^{2}$

Dasar hukum tentang kebolehan untuk kerja sama bagi hasil ini adalah berdasarkan Al-Qur'an. Sebagaimana yang difirmankan Allah SWT dalam AlQur'an Surat Al jumu'ah ayat : 10 yang artinya

apabila telah ditunaikan shalat, Maka bertebaranlah kamu di muka bumi; dan carilah karunia Allah dan ingatlah Allah banyak-banyak supaya kamu beruntung. ${ }^{3}$

Para ahli hukum Islam sepakat mengakui keabsahan mudharabah ditinjau dari segi kebutuhan dari manfaat pada suatu segi dan karena sesuatu dengan ajaran dan tujuan syari'ah dan segi lainnya. Cara penghitungan keuntungan dalam bagi hasil mudharabah yaitu dalam pembagian keuntungan harus dinyatakan dalam bentuk persentase antara kedua belah pihak. Bagi untung dan rugi bila laba besar, maka kedua belah pihak mendapatkan keuntungan yang besar dan sebaliknya. Menentukan besarnya keuntungan ditentukan berdasarkan kesepakatan masingmasing pihak yang berkontrak. ${ }^{4}$

Resiko kerugian dalam mudharabah, menurut ulama fiqh apabila di dalam transaksi tersebut mengalami kegagalan, yang mengakibatkan sebagian atau seluruh modal yang ditanamkan pemilik modal habis, maka yang menanggung kerugian hanya pemilik modal sendiri. Sedangkan penerima modal sama sekali tidak menanggung atau tidak harus mengganti kerugian atas modal yang hilang dalam catatan pengelola modal dalam menjalankan usahanya sesuai dengan aturan 
yang telah mereka setujui, tidak menyalah gunakan modal yang dipercayakan kepadanya.

Abdurrahman Al-Jaziri mengatakan mudharabah berarti ungkapan terhadap pemberian modal dari seseorang kepada kepada orang lain sebagai modal usaha di mana keuntungan yang diperoleh akan dibagi dua di antara mereka berdua, dan bila terjadi kerugian yang disebabkan bukan karena kesalahan yang menjalankan modal, dia berhak mendapatkan upah yang wajar disebut ujratul-mitsil. Praktik pada kelompok ternak Badan Usaha Milik Desa Suka Ramai Kecamatan Panyabungan Utara Kabupaten mandailing Natal, melakukan pengembangbiakan ternak khususnya pada hewan kambing atau bagi hasil pemeliharaan kambing yang dilakukan secara tradisional.

Namun sangat disayangkan disaat waktu panen hasil tiba kelompok ternak kambing Badan Usaha Milik Desa Suka Ramai melanggar perjanjian atau wanprestasi dimana perjanjian bagi hasil yang disepakati bersama tidak terlaksanakan. Dugaan pihak Badan Usaha Milik Desa mengatakan bahwa kelompok ternak yang dipercayakan mengelola kambing tersebut menganggap bahwa ternak kambing tersebut bersifat bantuan. Dan tidak menghiraukan perjanjian yang disepakati bersama, sehingga para kelompok ternak kambing tersebut menjual hasil perkembangbiakan kambing secara ilegal dan tidak memberikan bagi hasil pada Badan Usaha Milik Desa, sehingga menimbulkan dampak ketidak percayaan pemerintah terhadap sistem kerja Badan Usaha Milik Desa Suka Ramai yang akan membahayakan putusnya saluran Anggaran Badan Usaha Milik Desa untuk tahun berikutnya, karna dianggap tidak sukses menjalankan misi Badan Usaha Milik Desa tersebut.

Pihak Badan Usaha Milik Desa telah memberikan teguran bagi kelompok ternak kambing namun tidak dihiraukan, dan sebagaian anggota kelompok ternak mengatakan bahwa dana untuk Badan Usaha Milik Desa adalah bagian dari anggaran dana Desa yang Notabene nya anggaran tersebut dikucurkan pada masayarakat kecil seperti kami ini. Lalu kenapa kami harus memberikan bagian kepada pihak Badan Usaha Milik Desa, dengan suasana bersitegang yang tidak nyaman lagi ujar salah satu pihak Badan Usaha Milik Desa Suka Ramai kec. Panyabungan Utara kab. Mandailing Natal.

Dari masalah yang ada di lapangan serta sistem bagi hasil yang dilakukan kelompok ternak kambing dengan Badan Usaha Milik Desa Suka Ramai kec. 
70 AT-TAWASSUTH: Jurnal Ekonomi Islam, Volume VI No. 1

Januari - Juni 2021: 66 - 89

Panyabungan Utara kab. Mandailing Natal sangat menarik untuk saya teliti lebih luas lagi secara teoritis dan praktis dalam tinjauan hukum Islam. Agar masyarakat khususnya kelompok ternak kambing Badan Usaha Milik Desa Suka Ramai sadar akan penting nya rasa tanggung jawab dan tolong menolong bagi sesama individu dan kelompok. Islam adalah agama yang komprehensif, meliputi seluruh aspek kehidupan dengan segenap dimensinya. Karenanya, Allah Swt menjadikan agama yang sempurna ini sebagai anugerah bagi rakyat Islam.

\section{Kajian Teori}

\section{Konsep Mudharabah}

\section{Pengertian Mudharabah}

Madharabah arti asalnya "berjalan di atas bumi untuk berniaga" atau yang disebut dengan qiradh yang arti asalnya saling mengutang. Mudharabah mengandung arti "kerja sama dua pihak yang satu diantaranya menyerahkan uang kepada pihak lain untuk diperdagangkan, sedangkan keuntungannya dibagi diantara keduanya menurut kesepakatan. ${ }^{5}$

Mudharabah berasal dari kata ad-dharb yaitu bepergian untuk urusan dagang. Sebagaimana firman Allah dalam Al-Qur'an surah Al jumu'ah ayat : 10 yang artinya:

"apabila telah ditunaikan shalat, Maka bertebaranlah kamu di muka bumi; dan carilah karunia Allah dan ingatlah Allah banyak-banyak supaya kamu beruntung."

Selain ad-dharb, disebut juga qiradh yang berasal dari kata al-qardhu, berarti al-qath" $u$ (potongan) karena pemilik memotong sebagian hartanya untuk diperdagangkan dan memperoleh sebagian keuntungan. Ada pula yang menyebut mudharabah atau qiradh dengan muamalah Kata Mudharabah berasal dari kata dharaba pada kalimat al-dharab, yakni bepergian untuk urusan dagang. Menurut bahasa, kata Abdurrahman Al Jaziri, Mudaharabah berarti ungkapan terhadap pemberian harta seseorang kepada orang lain sebagai modal usaha yang keuntungannya dibagi antara mereka berdua, dan bila rugi akan ditanggung oleh pemilik modal.

Ada pula yang menyebut Qiradh dengan muamalah yakni akad antara kedua belah pihak untuk salah seorangnya (salah satu pihak mengeluarkan sejumlah uang kepada pihak lainnya untuk diperdagangkan dan laba dibagi 
sesuai kesepakatan). Istilah Mudharabah digunakan oleh orang irak, sedangkan orang Hijaz menyebutnya dengan istilah qiradh. Dengan demikian mudharabah dengan qiradh adalah dua istilah yang memiliki makna sama.

Mudharabah adalah sistem kerja sama usaha antara dua pihak atau lebih dimana pihak pertama (shahibul maal) menyediakan seluruh (seratus persen) kebutuhan modal sebagai penyuntik sejumlah dana sosial kebutuhan pembiayaan suatu proyek, sedangkan nasabah sebagai pengelola mengajukan permohonan pembiayaan dan untuk ini.

Nasabah sebagai pengelola (mudharib) menyediakan keahliannya Hasbi Ash Shiddieqy mengatakan bahwa mudharabah adalah semacam syarikat akad, bermufakat dua orang padanya dengan ketentuan: modal dari satu pihak, sedangkan usaha menghasilkan keuntungan dari pihak yang lain, dan keuntungan-keuntungan dibagi antara mereka.

2. Dasar Hukum Mudharabah

Adapun dasar hukum yang disyarieeatkannya mudharabah dalam Islam yaitu Ayat Al-Qur'an yang berkenaan dengan mudharabah, antara lain: Al-Qur'an Surat Al-Muzammil ayat 20 yang artinya:

"Sesungguhnya Tuhanmu mengetahui bahwasanya kamu berdiri (sembahyang) kurang dari dua pertiga malam, atau seperdua malam atau sepertiganya dan (demikian pula) segolongan dari orang-orang yang bersama kamu. dan Allah menetapkan ukuran malam dan siang. Allah mengetahui bahwa kamu sekali-kali tidak dapat menentukan batas-batas waktu-waktu itu, Maka Dia memberi keringanan kepadamu, karena itu bacalah apa yang mudah (bagimu) dari Al Quran. Dia mengetahui bahwa akan ada di antara kamu orang-orang yang sakit dan orang-orang yang berjalan di muka bumi mencari sebagian karunia Allah; dan orang-orang yang lain lagi berperang di jalan Allah, Maka bacalah apa yang mudah (bagimu) dari Al Quran dan dirikanlah sembahyang, tunaikanlah zakat dan berikanlah pinjaman kepada Allah pinjaman yang baik. dan kebaikan apa saja yang kamu perbuat untuk dirimu niscaya kamu memperoleh (balasan)nya di sisi Allah sebagai Balasan yang paling baik dan yang paling besar pahalanya. dan mohonlah ampunan kepada Allah; Sesungguhnya Allah Maha Pengampun lagi Maha Penyayang”. ${ }^{7}$

Adapun hadits yang berkaitan dengan mudharabah adalah hadits yang diriwayatkan oleh Ibnu Majah dari Shuhaib bahwa Nabi Muhammad SAW. Bersabda yang artinya:

Ada tia hal yang mengandung berkah: jual beli tidak secara tunai, muqaradhah (mudharabah) dan mencampur jewawut dengan gandum untuk keperluan rumah tangga, bukan untuk dijual. ${ }^{\mathbf{8}}$ 
72 AT-TAWASSUTH: Jurnal Ekonomi Islam, Volume VI No. 1

Januari - Juni 2021: 66 - 89

\section{Rukun dan Syarat Mudharabah}

Islam telah mengatur rukun dan syarat kerja sama mudharabah sehingga kerja sama itu dapat dikatakan sah oleh syara. Rukun adalah kata mufrad dari kata jama' 'arkan' artinya asas atau sendi atau tiang, yaitu sesuatu yang menentukan sah (apabila dilakukan) dan tidak sahnya (apabila ditinggalkan) sesuatu pekerjaan dan sesuatu itu termasuk di dalam pekerjaan itu.

Rukun mudharabah menurut sayyid sabiq adalah ijab dan qabul yang keluar dari orang yang memiliki keahlian. Dalam ijab qabul ini tidak disyaratkan adanya lafaz tertentu, akan tetapi dapat dengan bentuk apa saja yang menunjukkan makna mudharabah karena yang dimaksud dalam akad ini adalah tujuan dan maknanya, buka lafaz dan susunan katanya.

Adapun syarat sah akad mudharabah sangat terkait dengan rukun mudharabah sebagaimana yang telah disebutkan di atas yaitu bila berkenaan dengan syarat akad. Disyaratkan bagi orang yang akan melakukan akad, yakni pemilik modal dan pengusaha adalah ahli dalam mewakilkan dan menjadi wakil. Khususnya bagi pengusaha (mudharib) harus orang-orang benar mampu (ahli) serta jujur, bahwa dalam arti bahwa ia biasa dipercaya untuk menjalankan modal sekaligus menjaga modal yang dipercayakan kepadanya. Bila berkenaan dengan syarat modal bahwa Modal harus berupa uang, seperti dinar, dolar, atau rupiah. Modal harus diketahui dengan jelas dan memiliki ukuran. Modal harus ada, bukan berupa hutang, artinya modal yang diberikan itu benar-benar milik sendiri. Modal harus diberikan kepada pengusaha.

Hal ini dimaksudkan agar pengusaha dapat mengusahakannya, yakni menggunakan harta tersebut sebagai amanah. Berkenaan dengan sighat (ijab dan qabul). Secara umum dapat dikemukakan bahwa mudharabah sebenarnya merupakan sub sistem dari musaqah. Namun, para ahli fiqih Islam meletakkan mudharabah dalam posisi tersendiri dan memberikan dasar hukum yang khusus, baik dar segi teks Al-Qur'an maupun dari sunnah. Prinsip mudharabah adalah prinsp bagi hasil, yaitu perjanjian antara pemilik modal (uang atau barang) dengan pengusaha. 
Pada perjanjian ini pemilik modal bersedia membiayai sepenuhnya suatu proyek tersebut atau usaha, dan pengusaha setuju untuk pengelola proyek tersebut dengan pembagian hasil sesuai dengan perjanjian. ${ }^{9}$ Prinsip-prinsip mudharabah ini tidak terlepas dari prinsip-prinsip muamalah Islam. Oleh karenanya mudharabah ini harus tetap mengacu pada aturan syari'at Islam dan aturan Fiqih Muamalah menjadi indikatornya. Artinya sesuai atau tidaknya mekanisme dalam mudharabah ini sangat ditetukan kesesuaiannya dengan prinsip-prinsip muamalah Islam.

Adapun prinsp-prinsip mudharabah dalam muamalah Islam, yaitu pertama Prinsip kebolehan melakukan akad mudharabah. Artinya bahwa akad mudharabah itu dibenarkan oleh Al-Qur'an dan sunah Rasul. Dalam mudharabah harus tetap berpegang teguh pada ketentuan syari'at Islam sebagaimana telah dijelaskan pada landasan hukum mudharabah (Al-Qur'an dan Sunnah). Mudharabah dibolehkan karena memiliki manfaat bagi orang banyak, terutama bagi kaum lemah dan pengusaha tidak dikenakan tanggungan terhadap modal yang rusak (pailit) selama ia tidak melampaui batas dalam arti kerugian itu disebabkan konsekuensi dari bisnis. Kedua, Prinsip sukarela tanpa paksaan. Akad mudharabah mencerminkan kerelaan untuk bekerja sama, maka tidak boleh oleh salah satu pihak yang melakukan akad ini dalam kepentingan peribadi. Ketiga, Prinsip mendatangkan manfaat dan menolak kemudharatan. Sebagai mahluk sosial, kebutuhan akan kerja sama antara satu pihak dengan pihak lain guna meningkatkan taraf hidup khususnya dalam bidang ekonomi merupakan hal yang tidak bisa diabaikan.

Kenyataan menunjukan bahwa kehidupan manusia mempunyai modal, tetapi tidak bisa mengelola modal tersebut, dan berkeinginan membantu orang lain dengan jalan menalihkan modal yang dia miliki kepada pihak yang membutuhkan dan mampu mengelola modal tersebut. Berdasarkan kenyataan ini, maka diperlukan kerja sama antara yang memiliki modal dan orang yang tidak mempunyai atau kekurangan modal. Keempat, Prinsip keadilan. Sifat semangat, kebersamaan, dan keadilan tampak jelas dalam kerja sama mudharabah. Hal ini dapat dilihat melalui kebersamaan dalam menanggung kerugian yang dialami dalm usaha, kerugian akan ditanggung pemilik modal apabila kerugian itu merupakan akibat (konsekuensi) dari bisnis, bukan karena rekayasa. Pihak pengelola menanggung kerugian skill, dan waktu, sedangkan 
74 AT-TAWASSUTH: Jurnal Ekonomi Islam, Volume VI No. 1

Januari - Juni 2021: 66 - 89

apabila mendapatkan keuntungan akan dibagi bersama sesuai dengan kesepakatan yang telah disepakati oleh kedua belah pihak.

Berdasarkan uraian mengenai prinsip-prinsip mudharabah di atas, maka dapat disimpulkan bahwa sistem kerja sama antara pemilik modal dan pengelola dalam bentuk akad mudharabah ini sangat terasa ketika dapat membantu perekonomian kaum lemah yang mempunyai keahlian tetapi tidak memiliki modal untuk melakukan sebuah usaha guna memenuhi kebutuhan hidup, dan yang terpenting dapat mencegah kesenjangan sosial antara orang kaya dan miskin.

\section{Metode Penelitian}

Menurut jenisnya penelitian ini termasuk penelitian lapangan atau (Field Research). Jenis penelitian lapangan adalah penelitian yang bertujuan untuk mengumpulkan data dari lokasi atau lapangan. Yakni dari berbagai informasi yang berkaitan dari buku-buku yang membahas tentang mudharabah dalam kerja sama, termasuk juga data primer hasil wawancara dengan para pihak yang bersangkutan sebagai objek penelitian. Sedangkan penelitian ini bersifat deskriptif analisis yang memaparkan situasi dan peristiwa, tidak mencari dan mencari hubungan. Pada penelitian deskriptif, dititik beratkan pada observasi.

\section{Hasil dan Pembahasan}

\section{Sistem Bagi Hasil Ternak Kambing Antara Kelompok Ternak Dengan Badan Usaha Milik Desa Suka Ramai.}

1. Hak-hak dan Kewajiban Pemilik kambing dan Pemelihara?

a. Hak-hak dan kewajiban pemilik kambing

Pada kerja sama bagi hasil hewan ternak pemilik modal mempunyai beberapa hak dan kewajiban yaitu:

1) Pemilik modal berkewajiban menyediakan dan menyerahkan modal $100 \%$.

2) Pemilik modal mempunyai hak penuh atas modal yang diberikan kepada pekerja.

3) Pemilik modal berhak melakukan pengawasan terhadap jalannya kegiatan usaha. Meskipun pekerja tetap mempunyai hak eksklusif untuk mengelola tanpa campur tangan pemilik modal. 
Anjur Perkasa Alam : Pelaksanaan Bagi Hasil Ternak... $\mid 75$

b. Hak-hak dan kewajiban pekerja

Pekerja memiliki beberapa hak dalam akad kerja sama bagi hasil hewan ternak, yakni nafkah (living cost atau biaya hidup) dan keuntungan yang disepakati dalam akad. Ulama berbeda pendapat tentang hak pekerja atas aset mudharabah. Menurut Imam Syafe'i mudharib tidak berhak mendapatkan nafkah atas kebutuhan pribadinya dari aset mudharabah, baik di rumah atau dalam perjalanan.

Karena mudharib kelak akan mendapatkan bagian keuntungan dan ia tidak berhak mendapatkan manfaat lain dari akad mudharabah. Nafkah ini bisa jadi sama nominalnya dengan bagian keuntungan, dan mudharib akan mendapatkan lebih.

2. Bagaimana pelaksanaan bagi hasil ternak kambing pada kelompok ternak dengan Badan Usaha Milik Desa?

Adapun Sistem dan cara yang digunakan untuk membagi hasil ternak kambing yang digunakan dalam pelaksanaan perjanjian bagi hasilnya terdapat tiga cara yaitu :

a. Kerjasama dilakukan dengan cara satu ekor kambing betina dan kambing jantan yang dipercayakan pemiliknya kepada orang lain untuk dirawat. Dengan perjanjian bila kambing tersebut beranak yang pertama, maka anak kambing tersebut seluruhnya milik orang yang memeiharanya dengan kata lain pemilik kambing tidak memperoleh apa-apa selama kurun waktu tersebut. Setelah kambing tersebut dibagi dua antara pemilik kambing dan orang yang memelihara kambing. Dan begitu seterusnya.

b. Pembagian hasil dilakukan dengan perjanjian awal, apabila Kambing yang dipelihara sudah berkembang biak atau beranak maka seluruh kambing tersebut dijual kemudian dikurangi dengan modal dan sisa dari keuntungan hasil pengelolaan kambing tersebut barulah dibagi dengan pemelihara $40 \%$ dan pemilik $60 \%$.

c. Pembagiannya dilakukan dengan perjanjian apabila kambing yang dipelihara sudah berkmebang biak atau beranak maka antara pemilik kambing dan pemelihara kambing hanya secara 
76 AT-TAWASSUTH: Jurnal Ekonomi Islam, Volume VI No. 1

Januari - Juni 2021: 66 - 89

bergantian mendapatkan hasil. Misal kambing melahirkan anak pertama kali untuk pemilik kambing, dan jika kambing itu melahirkan kembali maka untuk pengelola dan begitu seterusnya.

\section{Akad-Akad Kerja Sama Bagi Hasil Ternak}

Akad memiliki posisi dan peranan yang sangat strategis dalam persoalan mudharabah. Dalam fiqhi Islam, ada beberapa jenis akad, salah satunya yang dimaksud disini adalah akad kerjasama (bagi hasil) Ternak kambing dibidang mudaharabah dikenal dengan istilah mutlak dan muqayyadah.

\section{Mudharabah Mutlak}

Menurut Muhammad Asy-Syarbini mudharabah mutlak adalah penyerahan modal seseorang kepada pengusaha tanpa memberikan batasan seperti berkata, saya serahkan uang ini kepadamu untuk diusahakan, sedangkan labanya akan dibagi antara kita, masingmasing setengah, seprtiga atau lain-lain. Sedangkan Menurut Syafie I Antonio mudharabah mutlaqah adalah bentuk kerja sama antara shahibul mal dan mudharib yang cakupannya sangat luas dan tidak dibatasi oleh spesifikasi jenis usaha, waktu dan daerah.

\section{Mudharabah Muqayyadah}

Menurut Muhammad Asy-Syarbini, mudharabah al-muqayyadah (terikat) adalah penyerahan modal seseorang kepada pengusaha dengan memberikan batasan. Seperti syarat bahwa pengusaha harus berdagang didaerah tertentu atau harus berdagang sepatu, atau membeli barang dari orang tertentu, dan lain-lain.

Dalam definisi lain juga menyebutkan bahwa mudharabah ialah kerjasama antara pemilik modal dan pengelolanya, sehingga usaha tersebut menghasilkan sesuatu. Hasilnya menjadi milik kedua belah pihak berdasarkan perjanjian yang telah disepakati.

\section{Tata Cara Bagi Hasil Produktif}

Pengertian perjanjian bagi hasil menurut Boedi Harsono yakni : Suatu bentuk perjanjian antara seorang yang berhak atas suatu ternak dan orang lain yang disebut pemelihara, berdasarkan perjanjian dimana pemelihara diperkenankan mengusahakan ternak itu dengan pembagian hasil diantara kelompok ternak dan badan usaha milik desa berhak atas ternak tersebut menurut imbangan yang telah 
disetujui bersama, misalnya masing- masing mendapat seperdua atau mendapat sepertiga bagian.

Pengertian perjanjian bagi hasil menurut Bushar Muhammad adalah Apabila pemilik modal memberi ijin kepada orang lain untuk mengerjakan atau mengelola dengan perjanjian, bahwa yang mendapat ijin itu harus memberikan sebagian dari hasil ternak ke pada pemilik modal.

Dalam masyarakat Desa Suka Ramai Kec. Panyabungan Utara Kab. Mandailing Natal. Lebih ditekankan ke aspek hukum adat yang sudah turun temurun mulai dari nenek moyangnya. Seperti yang diungkap oleh warga setempat, Memang bagi hasil produktif ini sudah berjalan lama, sistem yang dianut adalah sistem yang dulu dipraktikkan oleh nenek moyang kami. Dan sampai saat ini, Perjanjian bagi hasil tersebut dilakukan dengan tidak tertulis, walaupun seperti itu namun dalam masyarakat tidak pernah menimbulkan masalah. Sebab, dari sejak dulu.

Wawancara kepada bapak kepala desa pada tanggal 30 November 2019 di kantor kepala Desa Suka Ramai. Dengan pertanyaan bagaimana pendapat bapak kebolehan untuk kerja sama dalam hal ternak kambing? Kepala Desa Suka Ramai menjawab : hukum Dalam ajaran Islam bekerja sama atau mengelola sesuatu yang bermanfaat adalah merupakan suatu kewajiban bagi setiap manusia, sehingga manusia harus mampu melakukan berbagai aktivitas yang dapat menunjang kesejahteraan secara materi. Diantara sektor-sektor pekerjaan yang bisa kita lakukan salah satunya adalah pada sektor ternak kambing. Seperti yang dipraktekkan masyarakat Desa Suka Ramai Kec. Panyabungan Utara Kab. Mandailing Natal. Adalah salah satu Desa yang memiliki sektor ternak kambing. Bahkan, dalam masyarakat setempat masih ada lagi areal peternakan yang milik Badan Usaha Milik Desa dan dikelola, diperdayakan, serta dimanfaatkan oleh kelompok ternak setempat dengan aturan yang ditaati secara bersama-sama ${ }^{10}$.

Paparan kepala Desa ini sejalan dengan Ustaz Abdul Muksin Nasution 07 desember 2019 jam 14.20 wib dengan pertanyaan. Apa pandangan ustaz terkait pelaksanaan bagi hasil ternak kambing dengan Badan Usaha Milik Desa?

Ustaz Abdul Muksin Nasution menjawab : Alhamdulillah masyarakat sangat bersukur dengan adanya kegiatan bagi hasil produktif ternak kambing dari Badan Usaha Milik Desa Artinya, yang terbantu atau yang merasakan bukan saja masyarakat yang ikut sebagai kelompok ternak, tapi dari bagi hasil ternak produktif 
tersebut, diperdayakan untuk pembangunan Desa, seperti jembatan, mesjid, sekolah dan sebagainya. Semangat ini timbul melalui pesan ayat suci Alquran yang berbunyi "tolong menolong dalam kebajikan dan takwa". Mamfaatnya sangat besar di rasakan masyarakat, dia berharap keadaan seperti ini tetap di jaga dan dilestarikan ${ }^{11}$.

Sistem bagi hasil yang umum atau yang lazim diterapakn terdiri dari dua bentuk yaitu: Profit Sharing dan revenue sharing. Profit sharing merupakan perhitungan bagi hasil laba atau keuntungan dari pengelolaan dana yaitu pendapatan usaha dikurangi dengan beban atau biaya-biaya usaha untuk mendapatkan beban tersebut. Sedangkan revenue sharing merupakan sistem bagi hasil yang memperhitungkan sebelum dikurangi dengan beban usaha untuk mendapatkan pendapatan tersebut ${ }^{12}$.

Pembahasan dalam hal ini yang terpenting adalah maksud dan tujuan dari kerja sama bagi hasil antara Badan Usaha Milik Desa dan kelompok ternak. Adapun tujuan akad untuk mendapatkan laba atau keuntungan. Harga modal awal atau modal pokok ditentukan oleh pedagang kambing dan pedagang kambing itu didatangkan atas persetujuan kedua belah pihak.

Akad kerja sama antara Badan Usaha Milik Desa dan kelompok ternak kambing dijelaskan dalam bentuk perjajian kerjasama yang telah disetujui oleh kedua belah pihak. Bentuk akad dalam bagi hasil ini tidak dalam bentuk tertulis. Misalnya pihak Badan Usaha Milik Desa berkata : saya memberikan kambing ini untuk dipelihara. Salah satu anggota kelompok ternak menjawab: saya terima kambing ini untuk kami pelihara. Jadi antara pemilik dan pemelihara kambing hanya berdasarkan atas suka rela dan adanya rasa kecocokan diantara mereka. Kedua bentuk bagi hasil ini masing-masing memiliki kelemahan dan kelebihan. Pada profit sharing semua pihak yang terlibat dalam akad akan mendapatkan bagi hasil sesuai dengan laba yang diperoleh atau bahkan tidak mendapat bagi hasil apabila pengelola mengalami kerugian pada praktiknya.

Karena pengelola atau mudharib dapat meninggikan biaya oprasional seingga akan berpengaruh pada bagi hasil yang diterima nantinya, apabila biaya oprasional tinggi maka bagi hasil bersih dibagikan akan menjadi sedikit. Berbeda dengan revenue sharing kedua belah pihak akan mendapat bagi hasil dari seluruh pendapatan pengelola dana jika ditinjau dari pemilik dana maka bagi hasil ini akan 
menguntungkan, karena selama pengelolaan memperoleh revenue maka pemilik dana akan memperoleh bagi hasilnya.

Hubungan antara manusia sebagai individu atau sebagai anggota kelompok ternak dalam usaha memenuhi kebutuhannya ada bermacam-macam bentuknya, ada yang berupa jual beli, hutang piutang, sewa menyewa, kerjasama dan sebagainya. Dalam memenuhi kehidupan sehari-hari tidak cukup dengan hanya mengandalkan usaha bertani dan berkebun saja melainkan masyarakat setempat menjalankan usaha lainnya yakni usaha kerjasama bagi hasil ternak kambing dengan Badan Usaha Milik Desa yang sudah lama dijalani oleh penduduk Desa Suka Ramai.

Usaha bagi hasil ternak kambing dengan Badan Usaha Milik Desa di Desa Suka Ramai, para anggota tidak memberi nama dengan sistem mudharabah. Mereka hanya menyebutnya dengan sistem bagi hasil. Secara teoritis sistem bagi hasil ini berdasarkan konsep mudharabah karena dalam praktiknya sesuai dengan teori mudharabah, yaitu pemilik modal atau shahubul maal memberikan dana $100 \%$ kepada pengelola dana aatu mudharib yaitu berupa kambing tersebut. Sedangkan penulis tidak menyebutnya dengan musyarakah karena secara teori musyarakah merupakan sistem bagi hasil dimana kedua belah pihak memberikan kontribusi dana untuk menjelaskan suatu usaha atau proyek. Pelaksanaan kerjasama bagi hasil ternak kambing ada dua belah pihak yang terlibat di dalamnya, yaitu: pemilik modal dan pemelihara kambing.

Berdasarkan hasil wawancara dengan Ketua Badan Usaha Milik Desa yaitu : Bapak Dedi Candra Kirana pada tanggal 02 Desember 2019 dengan pertanyaan. Bagaimana sistem bagi hasil ternak kambing antara kelompok ternak dengan Badan Usaha Milik Desa? Ketua Badan Usaha Milik Desa menjawab : Adapun sistem dan cara yang digunakan untuk membagi hasil ternak kambing yang digunakan dalam pelaksanaan perjanjian bagi hasilnya terdapat tiga cara yaitu :

a. Kerjasama dilakukan dengan cara satu ekor kambing betina dan kambing jantan yang dipercayakan pemiliknya kepada orang lain untuk dirawat. Dengan perjanjian bila kambing tersebut beranak yang pertama, maka anak kambing tersebut seluruhnya milik orang yang memeiharanya dengan kata lain pemilik kambing tidak memperoleh apa-apa selama kurun waktu tersebut. Setelah kambing tersebut dibagi dua antara pemilik kambing dan orang yang memelihara kambing. Dan begitu seterusnya. 
80 AT-TAWASSUTH: Jurnal Ekonomi Islam, Volume VI No. 1

Januari - Juni 2021: 66 - 89

b. Pembagian hasil dilakukan dengan perjanjian awal, apabila kambing yang dipelihara sudah berkembang biak atau beranak maka seluruh kambing tersebut dijual kemudian dikurangi dengan modal dan sisa dari keuntungan hasil pengelolaan kambing tersebut barulah dibagi dengan pemelihara $40 \%$ dan pemilik $60 \%$.

c. Pembagiannya dilakukan dengan perjanjian apabila kambing yang dipelihara sudah berkmebang biak atau beranak maka antara pemilik kambing dan pemelihara kambing hanya secara bergantian mendapatkan hasil. Misal kambing melahirkan anak pertama kali untuk pemilik kambing. Dan beranak untuk kedua kali maka untuk kelompok ternak. ${ }^{13}$

Kerjasama bagi hasil ini hanya didasarkan unsur tolong menolong dan kepercayaan, sehingga pola kerjasama Badan Usaha Milik Desa mampu menguntungkan kedua belah pihak akad dilakukan secara lisan, tidak ada batas waktu yang ditentukan saat akad dilakukan modal sepenuhnya dari Badan Usaha Milik Desa. Seorang peternak harus memiliki keahlian dalam mengelola ternak kambing Begitu pula dengan bapak irwan nasution selaku peternak kambing yang dimana keuntungan yang diperoleh dalam bagi hasil ternak kambing sebenernya yang membantu perekonomian, namun lama dalam memperoleh hasilnya karena menunggu perkembanbiakan ternak kambing terebut.

Dengan demikian usaha ternak kambing ini sangat saling membantu satu sama lain. Latar belakang kepentingan yang saling membutuhkan yaitu pengelola membutuhkan modal dan pemilik ternak membutuhkan tenaga dan kemampuan pemelihara untuk memelihara kambing. Untuk memenuhi harapan tersebut maka kerjasama merupakan alternative yang baik dalam kegiatan kerjasama ternak kambing.

Berdasarkan hasil penelitian yang penulis kumpulkan dari berbagi macam kumpulan data, baik berupa wawancara dan observasi, maka penulis mengemukakan bahwa sistem bagi hasil yang diterapkan di Desa Suka Ramai dalam menjalankan ternak kambing ini belum sepenuhnya sesuai dengan syariat Islam, seperti :

1 Akad yang terjalin antara shoibul maal dengan mudharib hanya akad lisan bukan tulisan, sehingga jika jadi komplen pengelola tidak adak 
bukti yang kuat. Padahal dalam Islam setiap bermuamalah atau melakukan transaksi hendaknya ditulis.

2 Dalam pembagian hasil tehadap keuntungan yang diperoleh tidak sesuai dengan kesepakatan. Kesepakatan usaha tersebut Badan Usaha Milik Desa dengan kelompok ternak sama-sama melakukan kesapakatan awal, kejelasan mengenai usaha ternak kambing dan bagi hasilnya, bahwa badan usaha milik desa memberikan modal kepada kelompok ternak untuk dipelihara kambing tersebut.

Dan nantinya akan dibagi keuntungan dengan sistem bagi dua atau 50:50, hal ini sudah disepakati oleh kedua belah pihak, meskipun hanya akad lisan. Hanya saja pengelola ternak ini tidak membagi keuntungan kepada pemilik kambing sesuai dengan kesepakatan. Jika ada pengelola mengambil uang tersebut untuk keperluan usaha tersebut, maka hendaklah dijelaskan kepada pemilik dan jika ada perubahan akad maka dari awal harus dibicarakan kepada sehingga tidak terjadi kesalah pahaman, sehingga hal ini melanggar prinsip Islam yaitu menzalimi orang lain.

Pada umumnya sistem bagi hasil dilaksanakan dengan tujuan untuk saling tolong menolong untuk bekerjasama berusaha dalam suatu usaha dimana pihak pertama kelebihan dana dan pihak kedua kekurangan modal namum memiliki skill sehingga mereka dapat bekerjasama untuk menjalin usaha dan keuntungan dibagi bersama. Dengan adanya kerjasama bagi hasil ini diharapkan dapat meninggkatkan ekonomi keluarga, setidaknya menambah pendapatan kelompok ternak sedikit demi sedikit. Karena usaha ini berfungsi tolong menolong dalam berbuat kebaikan. Hanya saja masih ada yang belum sesuai seperti Syari'at Islam masih perlu diperhatikan pelaksanaannya. Berdasarkan hasil pembahasan diatas, jika dikaji lebih dalam, ternyata kerjasama bagi hasil antara Badan Usaha Milik Desa dan kelompok ternak kambing dapat dijadikan salah satu potensi yang memberikan keuntungan bagi masyarakat khususnya dalam pemenuhan kehidupan sehari-hari.

Tinjauan Hukum Islam Terhadap Pelaksanaan Bagi Hasil Ternak Kambing Dengan Badan Usaha Milik Desa Suka Ramai Kecamatan Panyabungan Utara Kabupaten Mandailing Natal.

Kegiatan usaha pengembangbiakan ternak terutama ternak kambing yang dilakukan oleh kelompok ternak di Desa Suka Ramai Kecamatan Panyabungan Utara Kabupaten Mandailing Natal. Dalam pengertiannya adalah bagian dari 
82 AT-TAWASSUTH: Jurnal Ekonomi Islam, Volume VI No. 1

Januari - Juni 2021: 66 - 89

hukum Islam di bidang mudharabah yang mengatur perilaku manusia dalam menjalankan hubungan ekonominya. Sedangkan kegiatan kerjasama dalam bentuk bagi hasil ada dua istilah dalam Al-Qur'an disebut al-aqdu' (akad) dan al-ahdu' $(\text { janji })^{14}$.

Dalam hal kerjasama setidaknya yang berhubungan dengan perjanian, yaitu kegiatan ternak yang dilakukan oleh masyarakat di Desa Suka Ramai Kecamatan Panyabungan Utara Kabupaten Mandailing Natal, pada pelaksanaannya terdapat konsep kerjasama yang sudah jelas dan dibenarkan oleh syara' selama kegiatan usaha tersebut tidak bertentangan kepada nilai-nilai syari'at Islam itu boleh saja.

Pada konsepnya, dimana antar individu atau kelompok manusia yang melakukan kerjasama ternak kambing tersebut terjalin ikatan ijab qabul yang menimbulkan akibat hukum dari kegiatannya, yakni pihak pemilik modal menyatakan kehendaknya dalam menyerahkan modalnya berupa hewan kepda orang yang bisa setuju menjalankan kegiatan kerjasama ternak kambing, kemudian dari perikatan tersebut menimbulkan akibat hukum dari perjanjian perikatan terhadap objeknya.

Bentuk perjanjian dibagi menjadi dua macam yakni perjanjiaan dalam bentuk tertulis dan perjanjian dalam bentuk lisan. Dalam Al-Qur'an Surat AlBaqarah ayat 282 :

"hai orang-orang yang berimsn, apabila kamu bermu"amalah tidak secara tunai untuk waktu yang ditentukan, hendaklah kamu menuliskannya. Dan hendaklah seorang penulis diantara kamu menuliskannya dengan benar". 15

Firman diatas disebutkan bahwa Allah SWT menganjurkan kepada manusia hendaknya suatu perikatan dilakukan secara tertulis, dihadiri oleh saksi-saksi, dan diberikan tanggung jawab individu yang melakukan perikatan, dan yang menjadi saksi. Selain itu, dianjurkan pula apabila suatu perikatan dilaksanakan tidak secara tunai, maka dapat dipegang suatu benda sebagai jaminannya.

Berdasarkan hasil observasi yang penulis lakukan di lapangan, penulis mendapatkan data bahwa dalam pelaksanaan bagi hasil ternak kambing pada prinsipnya semata-mata hanya sekedar tolong menolong sesama manusia dalam bidang ekonomi untuk memenuhi kebutuhan hidup sehari-hari. Dalam isi perjanjian lisan, yang dilakukan oleh para pihak yang melakukan kegiatan kerjasama ternak 
kambing tersebut mengandung prinsip yang mempunyai nilai-nilai ialah sebagai berikut :

1. Asas kejujuran dalam menjalankan kegiatan kerjasama ternak kambing tersebut dimana kedua belah pihak harus jujur dan bertanggung jawab antar kedua belah pihak kepada Allah SWT dan kepada masyarakat.

2. Asas kebebasan. Membebaskan kedua belah pihak dalam menjalankan kegiatannya ditentukan dan disepakati oleh sesuai dengan hak dan kewajiban yang telah kedua belah pihak sepakati.

3. Asas keadilan. Keseimbangan antar individu dari kedua belah pihak baik moral atau materil. Dituntut untuk melakukan hal yang benar dalam pengungkapan kehendak dan keadaan.

4. Asas kerelaan. Kegiatan usaha ini dilakukan oleh para pihak atas dasar rela tidak ada paksaan oleh pihak lain, dikarenakan untuk memenuhi kebutuhan hidup sehari-hari.

Berangkat dari penjelasan diatas, dapat diambil kesimpulan bahwa sistem bagi hasil ternak kambing. Berdasarkan hasil observasi yang penulis lakukan pada Badan Usaha Milik Desa Suka Ramai modal yang diberikan berupa kambing, kemudian membagi keuntungan dengan perjanjian membagi anak dari hewan tersebut, atau dapat juga berupa dalam bentuk uang dari hasil penjualan kambing. Hal demikian tentulah tidak dilarang oleh syari'ah Islam sebab banyak sekali sisi manfaat yang dapat diambil dari transaksi tersebut, seperti nilai tolong menolong antar sesama (ta"awanu) dan nilai-nilai persaudaraan (ukhuwah). Dalam pelaksanaan perjanjian juga dijelaskan mengenai resiko misalkan hewan yang dipelihara tersebut sakit atau mati maka kerugian tersebut ditanggung bersama, apabila matinya hewan tersebut bukan karna kelalaian atau disebabkan oleh pihak yang memelihara maka Badan Usaha Milik Desa tersebut tidak berhak meminta ganti rugi.

Melihat dari uraian diatas menurut penulis pelaksanaan bagi hasil ternak kambing dengan Badan Usaha Milik Desa Suka Ramai Kecamatan. Panyabungan Utara Kabupaten. Mandailing Natal. sesuai dengan ajaran Islam. Namun demikian dalam pelaksanaannya berdasarkan hasil observasi yang penulis lakukan masih ada kesenjangan teori hukum Islam dan aplikasi yang terjadi di Badan Usaha Milik Desa Suka Ramai Kecamatan Panyabungan Utara Kabupaten Mandailing Natal. 
Yaitu dalam hal pemenuhan akad, seperti pertanggung jawaban apabila hewan ternak mati akibat kelalaian pihak pemelihara. Ternyata banyak sekali akad yang tidak terpenuhi serta pembagian hasil yang dapat merugikan salah satu pihak dan memerlukan akad (perjanjian) yang lebih jelas lagi, untuk menghindari hal-hal yang tidak diinginkan dalam akad perjanjian bagi hasil ternak kambing tidak tertulis. Dalam kehidupan bermasyarakat banyak hal yang terjadi untuk saling tolong menolong dan saling menguntungkan satu sama lain, salah satunya adalah mudharabah yang berupa kerjasama dalam peternakan, perkebunan, pengairan, dan masih banyak lagi kegiatan mudharabah. dalam hal ini yang akan difokuskan oleh peneliti adalah pelaksanaan bagi hasil ternak kambing dengan Badan Usaha Milik Desa menurut hukum Islam. Sistem bagi hasil ternak kambing merupakan bentuk pemanfaatan kondisi yang ada untuk peternakan. dimana pembagian hasil terdapat dua unsur produksi, yaitu modal dan kerja atau tenaga dilaksanakan menurut perbandingan tertentu dari hasil ternak.

Pelaksanaan bagi hasil ternak kambing dalam Islam dilakukan dengan kedua belah pihak yang berakad, ada sebagai pemilik ternak dan ada sebagai pemelihara dan salah satu dari keduanya menyediakan modal atau ternak. Hal ini dikarenakan pengetahuan masyarakat tentang teori-teori yang berlaku jadi mereka melakukan kerjasama bagi hasil ternak ini dengan berdasarkan sistem yang turun temurun dari pendahulu-pendahulunya atau biasa disebut dengan adat kebiasaan setempat. Beberapa warga setempat sangat antusias dengan adanya pelaksanaan bagi hasil ternak kambing dengan konsep bagi hasil atas ternak Badan Usaha Milik Desa. Dengan konsep bagi hasil seperti ini, tentu masyarakat setempat akan lebih terjamin kesejahteraan serta kehidupan yang lebih layak. Sehingga masyarakat melihat tidak ada unsur penipuan, di saat bagi hasil produktif ternak Badan Usaha Milik Desa.

Bentuk kerja sama bagi hasil sudah lama dipraktikkan dan dikenal umat Islam, bahkan kerjasama berupa bagi hasil telah dipraktikkan oleh bangsa Arab sebelum turunnya Islam. Ketika Nabi Muhammad Saw berprofesi sebagai pedangang, Nabi sendiri sudah melakukan kerjasama bagi hasil dengan Khadijah. Demikian ditinjau dari hukum Islam, maka praktik seperti ini dibolehkan, baik menurut Alquran, hadist, maupun Ijma'. Sedangkan pendapat beberapa Jumhur ulama diantaranya Imam Malik, para ulama Syafiiyyah, Abu Yusuf dan 
Muhammad bin Hasan (dua murid Imam Abu Hanifah), Imam Hanbali dan Dawud Ad-Dzâhiry. Mereka menyatakan bahwa akad mudharabah (bagi hasil) diperbolehkan dalam Islam. Pendapat mereka didasarkan pada Al-Quran, dan Hadits.

" Apakah mereka yang membagi-bagi rahmat Tuhanmu? Kami telah menentukan antara mereka penghidupan mereka dalam kehidupan dunia, dan Kami telah meninggikan sebahagian mereka atas sebagian yang lain beberapa derajat, agar sebagian mereka dapat mempergunakan sebagian yang lain. dan rahmat Tuhanmu lebih baik dari apa yang mereka kumpulkan. ${ }^{16}$

Ayat diatas menerangkan kepada kita bahwa Allah SWT memberikan keluasan dan kebebasan kepada umat-Nya untuk bisa mencari rahmat-Nya dan karunia-Nya untuk bisa tetap bertahan hidup di muka bumi. Bahwa Allah SWT, menciptakan isi alam ini, sesungguhnya untuk dikembangkan serta dikelola dengan baik. Mengelola dengan baik, berarti ada hal-hal yang harus ditempuh agar alam ini tetap memberikan keseimbangan untuk kelanjutan hidup manusia.

"Ada tia hal yang mengandung berkah: jual beli tidak secara tunai, muqaradhah (mudharabah) dan mencampur jewawut dengan gandum untuk keperluan rumah tangga, bukan untuk dijual". ${ }^{17}$

Banyak sekali riwayat yang menerangkan bahwa para sahabat telah melakukan praktik mudharabah dan tidak ada dari mereka yang mengingkari kebolehannya. Mudharabah merupakan suatu bentuk akad kerjasama yang mensinergikan antara harta dan pekerjaan, maka hal ini diperbolehkan sebagaimana untuk memenuhi kebutuhan manusia. Hal ini tentu senada dengan praktik pelaksanaan bagi hasil ternak kambing dengan Badan Usaha Milik Desa Suka Ramai. Praktik ini merupakan sesuatu yang sangat kreatif, berinovasi, serta menguntungkan masyarakat secara umum. Sebab apa yang mereka kelola, hasil pun untuk mereka sendiri.

Di sini Islam memberikan solusi terbaik untuk kedua pihak agar bisa bersinergi dan bekerjasama sehingga keuntungannya pun bisa dirasakan oleh kedua pihak. Simbiosis mutualisme antara Badan Usaha Milik Desa dan kelompok ternak ini akan menjadikan produktivitas di bidang peternakan dan pemeliharaan kambing semakin meningkat. Seperti yang diungkapkan Tokoh Agama Desa Suka Ramai Bapak Abdul Muksin Nasution, 07 Desember 2019 14.20 Wib.

Alhamdulillah masyarakat sangat bersukur dengan adanya kegiatan bagi hasil produktif ternak kambing dari Badan Usaha Milik Desa Artinya, yang 
86 AT-TAWASSUTH: Jurnal Ekonomi Islam, Volume VI No. 1

Januari - Juni 2021: 66 - 89

terbantu atau yang merasakan bukan saja masyarakat yang ikut sebagai kelompok ternak, tapi dari bagi hasil ternak produktif tersebut, diperdayakan untuk pembangunan Desa, seperti jembatan, mesjid, sekolah dan sebagainya. Semangat ini timbul melalui pesan ayat suci Alquran yang berbunyi "tolong menolong dalam kebajikan dan takwa". Mamfaatnya sangat besar di rasakan masyarakat, dia berharap keadaan seperti ini tetap di jaga dan dilestarikan. ${ }^{18}$

Oleh sebab itu Mudharabah ini disyariatkan oleh Allah SWT demi kepentingan kedua belah pihak. Kaum muslimin sudah terbiasa melakukan kerja sama semacam itu hingga zaman ini sehingga di berbagai masa dan tempat tanpa ada ulama yang menyalahkannya. Ini merupakan konsensus yang diyakini umat, karena cara ini sudah digunakan bangsa Quraisy secara turun temurun dari jaman jahiliyah hingga zaman Nabi Muhammad SAW, kemudian beliau mengetahui, melakukan dan tidak mengingkarinya.

Maka syariat membolehkan kerja sama ini agar mereka bisa saling mengambil manfaat diantara mereka. Shahibul mal (investor) memanfaatkan harta. Dan Mudharib (pengelola) memanfaatkan keahlian dan dengan demikian terwujudlah kerja sama harta dan amal. Allah SWT tidak mensyariatkan satu akad kecuali untuk mewujudkan kemaslahatan dan menolak kerusakan. Islam mensyariatkan akad kerja sama mudharabah untuk memudahkan orang, karena sebagian mereka memiliki harta namun tidak mampu mengelolanya dan disana ada juga orang yang tidak memiliki harta namun memiliki kemampuan untuk mengelola dan mengembangkannya.

Di dalam Islam hubungan antar manusia telah diatur sedemikian rupa agar tidak terjadi perselisihan yang mampu menimbulkan permusuhan antara individu satu dengan lainnya. Seperti halnya hubungan bisnis ataupun perniagaan antar individu. Apabila tidak dilandaskan hukum Islam, maka kecurangan dan kekecewaan pasti akan dirasakan oleh salah satu pihak yang terlibat. Dari beberapa kemungkinan buruk tersebut, maka hendaklah setiap melakukan pekerjaan ataupun hubungan bisnis dengan orang lain dilandaskan hukum agama agar kedua belah pihak tidak merasa dirugikan. Manusia dijadikan Allah SWT sebagai makhluk sosial yang saling membutuhkan antara satu dengan yang lain. Untuk memenuhi kebutuhan hidupnya, manusia harus berusaha mencari karunia Allah SWT yang ada dimuka bumi ini sebagai sumber ekonomi. Dalam kehidupan sosial, Nabi 
Muhammad SAW mengajarkan kepada kita semua tentang mudharabah agar terjadi kerukunan antar umat serta memberikan keuntungan bersama.

Hasil penelitian ini menyimpulkan bahwa, Pelaksanaan Bagi Hasil Ternak Kambing Dengan Badan Usaha Milik Desa Suka Ramai Kec. Panyabungan Utara Kab. Mandailing Natal. yaitu kerjasama antara kelompok ternak dengan Badan Usaha Milik Desa dimana pihak Badan Usaha Milik Desa memberi tugas kepada kelompok ternak. Untuk memelihara dan dikembangbiakkan ternak kambing dengan imbalan bagi hasil yang sesuai perjanjian yang disepakati dimana biaya dari keseluruhan mulai dari pemeliharaan sampai panen dari ternak dikeluarkan terlebih dahulu dari hasil penjualan. Masyarakat Desa Suka Ramai Kec. Panyabungan Utara Kab. Mandailing Natal merupakan mayoritas petani khususnya di sektor pertanian di samping mengelola kebun sendiri, juga masyarakat memiliki Badan Usaha Milik Desa yaitu ternak kambing yang di kelola kelompok ternak atas kesepakatan unsur Desa yakni persetujuan dari Kepala Desa siapa saja yang ikut untuk dipekerjakan. Sedangkan sistem bagi hasil yang sesuai dengan kesepakatan atau adat istiadat setempat. Pada umumnya kerjasama ini berdasarkan pada kata sepakat atau kepercayaan antara kedua pihak dan dengan akad secara lisan, sehingga memberi peluang antara kedua pihak melakukan hal-hal yang dapat merugikan, seperti dalam isi perjanjian, hak dan kewajiban kedua pihak, pembagian bagi hasil yang belum tentu sama dan sesuai dengan prinsip hukum Islam.

Akhirnya analisis penulis, pembagian tersebut menggambarkan bahwa kedua belah pihak antara kelompok ternak sebagai pekerja dengan Badan Usaha Milik Desa saling membantu, saling tolong menolong, dan inilah yang diinginkan hukum Islam.

Bahkan yang paling unik adalah, sebagian masyarakat yang bekerja, malah dia dapat merasakan hasil dari apa yang di kerjakan kelompok ternak. Artinya, masyarakat sebagai pekerja mendapat dua kali untung dari upah sebagai kelompok ternak dan sebagai masayarakat Desa Suka Ramai yang merasakan pasilitas dari hasil Badan Usaha Milik Desa.

\section{Kesimpulan}

pelaksanaan bagi hasil ternak kambing dengan Badan Usaha Milik Desa Suka Ramai Kec. Panyabungan Utara Kab. Mandailing Natal dalam mudharabah pemelihara hanya bertanggung jawab atas pemeliharaan dan pengembangbiakan. 
Sebagai imbalan, kelompok ternak berhak atas nisbah tertentu dari hasil ternak. Berbeda dengan muqayyadah, dalam pemilik ternak menyerahkan kambing pada si pemelihara untuk diternakkan dan dipelihara dengan imbalan tertentu (nisbah) dari hasil jual kambing tersebut.

Jika ditinjau secara hukum Islam, praktik bagi hasil mudharabah di Desa Suka Ramai Kec. Panyabungan Utara Kab. Mandailing Natal sudah memenuhi kriteria hukum Islam, karena dengan alasan, Praktik bagi hasil ternak tersebut sudah menjadi adat kebiasaan setempat. Sedangkan dalam hukum Islam adat dapat dijadikan hukum, dengan kaidah “Adat kebiasaan dapat dijadikan hukum”. Tidak menimbulkan perselisihan karena saling ridho. Praktik bagi hasil ternak kambing tersebut saling menguntungkan antara kelompok ternak dan pihak Badan Usaha Milik Desa. Adanya asas tolong menolong. Sedangkan hikmah atau tujuan adanya kerjasama : pertama, terwujudnya kerjasama yang saling menguntungkan antara kelompok ternak dengan Badan Usaha Milik Desa. kedua, meningkatnya kesejahteraan masyarakat. ketiga, tertanggulanginya kemiskinan. keempat, terbukanya lapangan pekerjaan. $2002)$ h. 4

${ }^{1}$ Muhammad Syafi'I. Bank Syariah dari Teori Kapraktik. ( jakarta : Gema Insani Press.

${ }^{2}$ Hendi Suhendi. Fiqh Muamalah. (jakarta: Rajawali pers. 2011) h.135 2008) h. 83

${ }^{3}$ Departemen Agama RI. Al-Qur'an dan Terjemahannya (Bandung: CV Diponegoro.

${ }^{4}$ Harun Nasrun. Fiqh Muamalah. (jakarta : Gaya Medika Pratama. 2007) h.231

${ }^{5}$ Amir Syaripuddin, Garis Garis Besar Fiqih, ( Bogor, Kencana, 2003 ) h, 244

${ }^{6}$ Depertemen Agama RI, Al-Qur"an dan Terjemahannya (Bandung: CV Diponegoro.2008) h. 575

${ }^{7}$ Departemen Agama RI, Al-Qur'an dan Terjemahnya, ( Jakarta: Institut Ilmu Al-Qur'an ) h 2289

${ }^{8}$ Abu Abdullah bin Yazid Ibnu Majah, Sunan Ibnu Majah,( Darun Nasyr Al Misyriyah )

${ }^{9}$ Muhammad, Dasar-Dasar Keuagan Islam, ( Yogykarta: Ekonosia Kampus Fakultas Ekonomi UII, 2004 ) h. 84

${ }^{10}$ Rahmad Wahyudi. Kepala Desa, Wawancara Pribadi. Desa Suka Ramai, 30 November 2019 jam 09.30 Wib.

${ }^{11}$ Abdul Muksin Nasution. Tokoh Agama, Wawancara Pribadi. Desa Suka Ramai, 07 Desember 2019 jam 14.20 Wib.

${ }^{12}$ Muhammad, Manajemen Bank Syari“ah, (Yogyakarta : UPP AMP YKPN, 2002), h. 101

${ }^{13}$ Dedi Candra Kirana : Ketua Badan Usaha Milik Desa.Wawancara Pribadi. Desa Suka Ramai Kecamatan Panyabungan Utara Kabupaten Mandailing Natal. Tanggal 02 Desember 2019

${ }^{14}$ Gemala Dewi dkk, Hukum Perikatan Islam Di Indonesia, (Jakarta: Badan Penerbit Fakultas Hukum Universitas Indonesia, Kencana, 2007) h.45

${ }^{15}$ Departemen Agama RI, Al-Qur"an dan Terjemahnya, ( Jakarta: Institut Ilmu AlQurean ) h.345 
${ }^{6}$ Departemen Agama RI, Al-Qur"an dan Terjemahnya, ( Jakarta: Institut Ilmu Al-

${ }^{17}$ Ibid. h 49

${ }^{18}$ Ibid. h 38

\section{Daftar Pustaka}

Abdul Muksin Nasution . Tokoh Agama, Wawancara Pribadi. Desa Suka Ramai, 07 Desember 2019 jam 14.20 Wib.

Abu Abdullah bin Yazid Ibnu Majah, Sunan Ibnu Majah, Darun Nasyr Al Misyriyah

Amir Syaripuddin, Garis Garis Besar Fiqih, Bogor, Kencana, 2003

Dedi Candra Kirana : Ketua Badan Usaha Milik Desa.Wawancara Pribadi. Desa Suka Ramai Kecamatan Panyabungan Utara Kabupaten Mandailing Natal. Tanggal 02 Desember 2019

Departemen Agama RI, Al-Qur"an dan Terjemahnya, Jakarta: Institut Ilmu AlQurean

Departemen Agama RI, Al-Qur'an dan Terjemahnya, Jakarta: Institut Ilmu AlQur'an

Departemen Agama RI. Al-Qur'an dan Terjemahannya Bandung: CV Diponegoro. 2008

Depertemen Agama RI, Al-Qur"an dan Terjemahannya Bandung: CV Diponegoro.2008

Gemala Dewi dkk, Hukum Perikatan Islam Di Indonesia, Jakarta: Badan Penerbit Fakultas Hukum Universitas Indonesia, Kencana, 2007

Harun Nasrun. Fiqh Muamalah. jakarta : Gaya Medika Pratama. 2007

Hendi Suhendi. Fiqh Muamalah. jakarta: Rajawali pers. 2011

Muhammad Syafi'I. Bank Syariah dari Teori Kapraktik. jakarta : Gema Insani Press. 2002

Muhammad, Dasar-Dasar Keuagan Islam, Yogykarta: Ekonosia Kampus Fakultas Ekonomi UII, 2004

Muhammad, Manajemen Bank Syari"ah, Yogyakarta : UPP AMP YKPN, 2002

Rahmad Wahyudi. Kepala Desa, Wawancara Pribadi. Desa Suka Ramai, 30 November 2019 jam 09.30 Wib. 